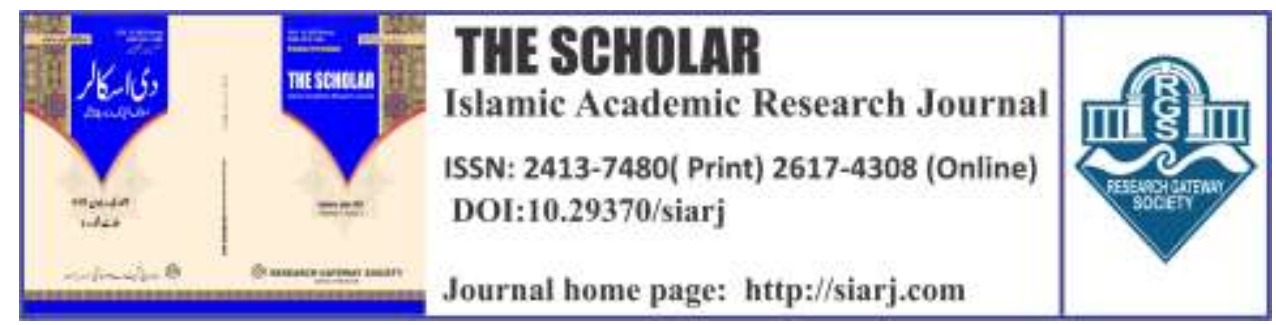

\title{
OVERVIEW OF IMPACTS OF TECHNOLOGY AND DIGITALIZATION ON FAMILY DYNAMICS: AN ISLAMIC PERSPECTIVE
}

\section{Asma Shahid}

Ph.D. Scholar, Institute of Islamic Studies, University of the Punjab, Lahore.

Email: asmaravian.pu@gmail.com

ORCID ID

https://orcid.org/0000-0002-4214-0226

\section{Aqsa Tasgheer}

Ph.D. Scholar, Institute of Islamic Studies, University of the Punjab, Lahore.

Email: aqsatasgheer201@gmail.com ORCID ID:

https://orcid.org/0000-0002-4214-0226

To cite this article:

Tasgheer, Aqsa, and Asma Shahid. "OVERVIEW OF IMPACTS OF TECHNOLOGY AND DIGITALIZATION ON FAMILY DYNAMICS: AN ISLAMIC PERSPECTIVE." The ScholarIslamic Academic Research Journal 7, No. 2 (December 30, 2021).

To link to this article: https://doi.org/10.29370/siarj/issue13ar2

Journal

Publisher

DOI:

URL:

License:

Journal homepage

Published online:
The Scholar Islamic Academic Research Journal Vol. 7, No. 1 || July-December 2021 || P.20- 35 Research Gateway Society 10.29370/siarj/issue13ar2 https://doi.org/10.29370/siarj/issue13ar2 Copyright c 2017 NC-SA 4.0 www.siari.com 2021-12-05
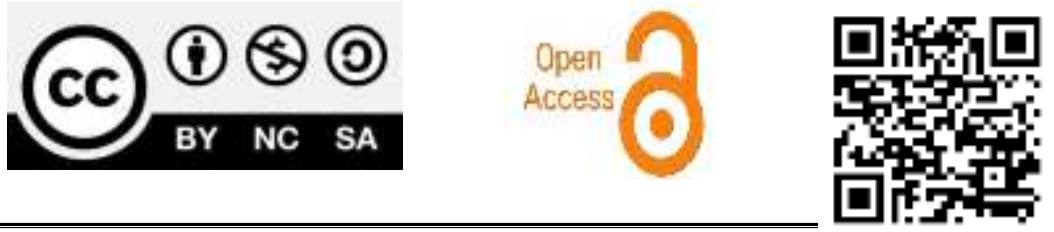
THE SCHOLAR (July-December 2021)

\title{
OVERVIEW OF IMPACTS OF TECHNOLOGY AND DIGITALIZATION ON FAMILY DYNAMICS: AN ISLAMIC PERSPECTIVE
}

\author{
Asma Shahid, Aqsa Tasgheer
}

\begin{abstract}
:
Technology and Digitalization has greatly influenced family system and culture. Familial values and socialization approaches are also shifting for the past few decades due to communication media. Latest technologies and digital advancement have manifold and diverse effects on marital relations and familial interactions. Nevertheless, it is still an issue of debate that whether the power of this digital advancement and its widespread accessibility has constructive or destructive outcomes in various aspects of family life. This paper will investigate the evolving patterns in which families engage as a consequence of recent technological development. Pakistani families, in particular, will be observed in this regard. Islam is a complete code of life furnishing patterns for ideal family life. In this research paper strategies and foundations for shaping digital transformation from a family viewpoint and Islamic perspective will be studied. In the end, recommendations will
\end{abstract}


be given that how digital encroachment can be advantageous to boost family dynamics.

KEY WORDS: Technology, Digitalization, Family, Dynamics, Islam INTRODUCTION:

Technology has assumed control over a significant part of human life all over the globe. The role of technology as an impetus to bring change cannot be denied, it has brought such a large number of good and illeffects that are difficult to ignore. Family as a basic unit of society has been enormously affected by technology and digitalization.

In the contemporary era, connections amid people have altered with the manifestation and advancement of networks and computers. Societal connections are beginning towards the web. Individuals convey, interconnect and shape connections utilizing public networks. ${ }^{1}$

\section{IMPORTANCE OF RESEARCH:}

In this era of technology and digitalization, new devices and means of communication have become popular in Pakistani homes, such as personal mobile phones, laptops, and tablets, etc. Sociologists and Social scientists are arguing about constructive and destructive results of digitalization on human life, especially family life. Family is the most important and primary unit of society. There is a dire need to research that how does the

${ }^{1}$ Badrul Hakim bin, A., Adilah Binti Abdullah, N., \& Binti Wan Mohd Azmi, W. F. (2016). The Negative Impact of Technology on Social Networking among Students at UTM Skudai 2016. Nova Journal of Engineering and Applied Sciences, 5(1), 1-12. https://doi.org/10.20286/nova-jeas-050102 
use of technology affects family dynamics and the traditional family, considering scientific innovations, easily accessible, and the prevalence of not only ICTs, but also tv, computer games, and entertainment gadgets? The significance of the research lies in revealing the positive and negative aspects of digitalization and technology on family dynamics.

\section{RESEARCH OBJECTIVE:}

In this era of digitalization, technology and media affect the dynamics of family life. Each nation is trying to promote its culture with the assistance of media, which has made a direct effect on life. This study aims to:

- Shed light on positive aspects of digitalization on family life

- Enlighten the risk of technology on thought, conduct, morals, and socialization behaviors of family

- Highlight Islamic teachings to tackle the challenges of digitalization on family life

\section{RESEARCH METHODOLOGY:}

A qualitative approach has been applied in this research paper. Different articles, newspapers, magazines, Internet sources, as well as books, have been used for data collection.

\section{DIGITALIZATION:}

In recent years, the term "digitalization" has been widely attractive in public discourse, with several different variations of the phrase being employed.

In general, the impact and repercussions of information and communication technology on society and its systems (e.g., economic, 
political, cultural, and social) are clarified by utilizing the term "digitalization." Since the term "digitalization" was introduced, the consequences of digitalization on society have been a matter of great debate. In an article published in the North American Review in 1971, the term "digitalization" was first used concerning computerization. ${ }^{2}$

Digitalization is the use of digital technologies and digitized information to facilitate or streamline processes. Digitalization boosts efficiency and output while lowering expenses or efforts. It enhances rather than converts an old procedure or practice. It transforms a human-driven activity or chain of actions into a technology process. ${ }^{3}$ There exists a difference between digitization and digitalization. Digitization is the procedure of converting real items or properties into digital data. Digitalization is the use of digital technologies and digital data to enable or improve processes. $^{4}$

The study and exploration of the topic of digitalization have resulted in a massive volume of literature highlighting how the digital media system forms and influences the modern world. Digitalization has begun to address the structuring of various aspects of social life around digital communication and media infrastructure in this framework. In the contemporary era, connections amid people have transformed with the

${ }^{2}$ Tilen Gorenšek, "Conceptualization of Digitalization : Opportunities and Challenges for Organizations in the Euro-Mediterranean Area," International Journal Euro-Mediterranean Studies 12, no. 2 (2018): 93115.

${ }^{3}$ What is Digitization, Digitalization, and Digital Transformation | ARC Advisory https://www.arcweb.com/blog/what-digitization-digitalization-digitaltransformation Accessed: 2021-11-13

${ }^{4}$ ibid 
demonstration and progression of webs and computers. Familial and societal connections are altering because of digitalization. Individuals of a family communicate, interrelate and shape connections using public networks.

\section{SIGNIFICANCE OF FAMILY INSTITUTION IN ISLAM:}

The family is a Heavenly ordained and divinely inspired entity. It was not developed through a series of trials and errors carried out by humans over a long period. It was an institution that came into being with the emergence of man.

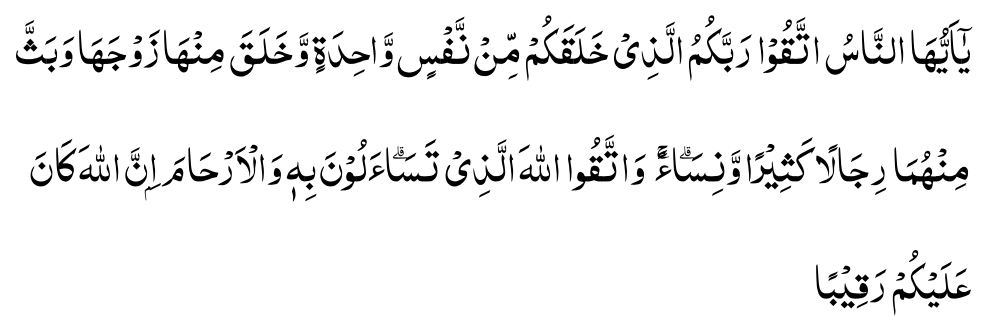

O men, fear your Lord who created you from a single soul, and from it created its match, and spread many men and women from the two. Fear Allah in whose name you ask each other (for your rights), and fear (the violation of the rights of) the womb-relations. Surely, Allah is watchful of you $^{5}$.

Marital institution has been praised as the way of the Prophets, as stated in the Holy Quran,

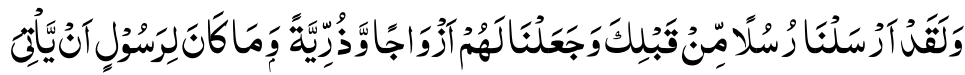

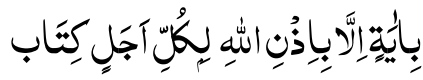

\section{${ }^{5}$ Al-Nisa 4:1}




\section{Overview of Impacts of Technology and Digitalization on Family Dynamics}

$\overline{\text { We have sent messengers before you and gave them wives and children. It }}$ is not for a messenger to bring a verse without the will of Allah. For every age, there are some rules prescribed ${ }^{6}$.

"Marriage is a component of my Sunnah," Prophet Muhammad (peace be upon him) remarked. "Whoever runs away from my path is not from among us." 7

Even though marriage is a divinely created institution, each marriage is essentially a contract. The word Nikah, which is used in the Quran and the Sunnah to refer to marriage, is derived from the Arabic word 'aqd, which means contract. In Surah Nisa, it is referred to as "Firm covenant". 8

The creation of man and woman, as well as the harmonious, compassionate, and merciful marriage union, have been portrayed as "signs of God", as referred to in Quran,

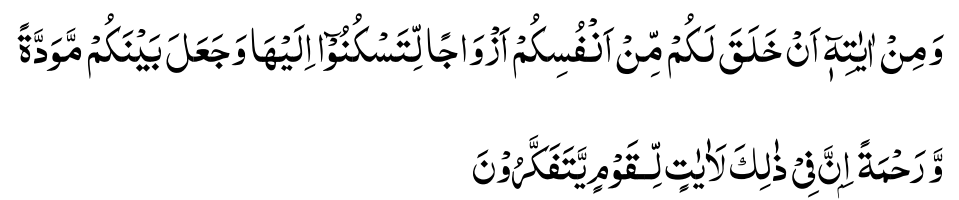

And it is among His signs that He has created for you wives from among yourselves, so that you may find tranquility in them, and He has created love and kindness between you. Surely in this, there are signs for people who reflect. ${ }^{9}$

It shows that one of the aims of marriage is to find psychological, moral, and personal fulfillment. The sense of connection, between all of its

\footnotetext{
${ }^{6} \mathrm{Ar}-\mathrm{Ra}$ 'ad 13:38

${ }^{7}$ Sunan Ibn-e-Maja, The Book of Marriage (Kitab-un-Nikah), Chapter 1, Hadith 1846

${ }^{8}$ An.-Nisa 4:21

${ }^{9}$ Ar-Rome 30:21
} 


\section{Overview of Impacts of Technology and Digitalization on Family Dynamics}

members, and, most importantly, between husband and wife, is more than just a pragmatic alliance. It is a divine bond that fosters and nurtures love, tolerance, compassion, mutual understanding, identity, comfort, and moral support. The blossoming of these partnerships represents the best of humankind. The virtues of togetherness, empathy, and affection, sacrificing for others, acceptance and generosity are accomplished and embedded in character when children grow up in the family. The family provides the most conducive environment for the growth and fulfillment of human identity. ${ }^{10}$

The family is a socialization agent and the main source of influence in the development of a person's upbringing and development. ${ }^{11}$

\section{SOCIAL MEDIA SIGNIFICANCE:}

The media has become an essential component and substantial impact on our everyday routines. The availability of media access is a strong instrument that contemporary society employs not just to entertain but also to communicate and educate. Nevertheless, there is an ongoing discussion about whether the potency of this impact and its widespread availability have positive or harmful repercussions in various areas of life. ${ }^{12}$

The computer may be one of the many devices that may be found in today's Pakistani homes. With the swift advancement of technological

${ }^{10}$ Islamic Approach and The Foundations, "Family Life in Islam 1. Islamic Approach to Life: The Foundations," 1974, 36, http://shibircloud.com/pdf/family_life_in_islam.pdf.

${ }^{11}$ Macionis, J. (2011). Sociology (Canadian) (7th ed.). Toronto, Canada: Pearson Education. Retrieved from http://www.textbooks.com

12 Alessondra Villegas, "The Influence of Technology on Family Dynamics” 2012 (2013). 


\section{Overview of Impacts of Technology and Digitalization on Family Dynamics}

advancements, it is hard to determine the impact that these devices have on how a family communicates. There is evidence to support both sides of the debate that the media is harming or fostering family relationships. "There are others who regard computers and the Internet as a beneficial force that will stimulate increased communication and better access to education, promote global understanding, and make the world a better place to live," as some detractors point out. ${ }^{13}$

Others argue that "computer technology would foster impoverished connections, isolation of persons within families, and alienation between families and the outside world," according to opponents. ${ }^{14}$

\section{USAGE OF TECHNOLOGY IN PAKISTAN:}

People in Pakistan, are swiftly catching up in terms of technology use, particularly smartphone and social media usage. Digital technologies are rapidly growing, resulting in the introduction of new services and software that are changing the way people live, operate, entertain, and interact. Digital technology adoption and use on a big scale in society is the main factor of measurable economic, social, and cultural values. ${ }^{15}$

${ }^{13}$ Rheingold, H. (1993). The virtual community: Homesteading on the electronic frontier. Cambridge, MA: Perseus Books.

${ }^{14}$ Stoll, C. (1995). Silicon snake oil: Second thoughts on the information highway. New York: Doubleday

${ }^{15}$ Jan Stryjak and Henry James, "Country Overview: Pakistan A Digital Future," 2016, www.gsmaintelligence.com. 


\section{Overview of Impacts of Technology and Digitalization on Family Dynamics}

In Pakistan, smartphone penetration has increased at an incredible rate over the last decade, as in 2002 only $5 \%$ population had mobiles but now $53 \%$ of the population has mobile phone access. ${ }^{16}$

Before the advent of modern technologies and media, parents or elders of the family used to nurture their children conveying religious beliefs and moral values in them. But in the contemporary age, this duty has also been "digitalized", for example, children no more listen to stories from grandmothers, rather they are given mobiles to watch videos (though constructive ones). Media and technologies are playing a role to impart information and ideologies of life to young ones.

\section{IMPACTS OF TECHNOLOGY AND DIGITALIZATION ON FAMILY LIFE:}

The fastest increasing technology and digitalization, which include phones and laptops, have been one of the most momentous advances in technology affecting family dynamics in the past few decades. Singlepurpose devices, such as cell phones, have already seen the most modifications, with many now having internet service and have become double or multi-purpose instruments.

Rapid advancement in TV, online resources, computers, mobile phones, and entertainment devices, to name a few, are all examples of how technology is continually shifting and families and individuals are affected by technological innovations.

\footnotetext{
16 The rise of mobile and social media use in Pakistan - Pakistan DAWN.COM

https://www.dawn.com/news/1142701/the-rise-of-mobile-and-socialmedia-use-in-pakistan Accessed: 2021-11-01
} 


\section{Overview of Impacts of Technology and Digitalization on Family Dynamics}

The use of new technology in the home has sparked controversy over whether children should be using computers and at what age, what technology should be used and how often, and how technology might affect family dynamics. In the household, technologies are typically used to make life easier, such as the usage of a microwave to speed up and simplify cooking. Then came the development of technologies for amusement, such as the television and numerous game devices. Finally, using the internet at home allows families to acquire knowledge and keep in touch with extended family members. ${ }^{17}$

By use of technology and the internet at home has also allowed for job flexibility, allowing family members to work from residence.

\section{CHANGE IN FAMILY LIFE STANDARDS:}

Digitalization has affected the life of every family on earth that came in link with it. It made tremendous transformations in the economic field. The term "digitalization" is mostly referred to as economic swifts as a result of technology and digital innovations. The economic field is affected by digitalization, which resulted in social makeovers.

Hundreds of years ago life was not as easier as today, even after having wealth. Technology has improved living standards providing cheap and comfortable gadgets and assistance. ${ }^{18}$

Improved living standards, as a result, transformed the ways families live and interact. Now children are more inclined to do the things themselves at

\footnotetext{
${ }^{17}$ Villegas, "The Influence of Technology on Family Dynamics."

${ }^{18}$ How Technology is Improving Living Standards - IntelligentHQ https://www.intelligenthq.com/technology-improving-living-standards/ Accessed: 2021-11-03
} 
The Scholar Islamic Academic Research Journal

Vol. 7, No. 2 || July-December 2021 || P. 1-19

https://doi.org/10.29370/siarj/issue13ar1

a very young age with the help of technology. The degree of comfort and ease in relations enhances when the standard of life is improved.

\section{HOUSEHOLD TECHNOLOGY AND FAMILY LIFE:}

Housewives are now happier as technology has given them ease providing dishwashers, automatic machines, household gadgets, and kitchen electronic devices. A housewife now has more time to spend with her family, take care of her husband and children.

Ruth S. Cowan states while talking about the interaction of technology and society we often think about workplace advancements, online business, massive computers, construction via technology, etc., but we ignore the technological revolution and digitalization in households of a family. This revolution has transformed our lives in unexpected ways. From hand power to electric power, from wood and coal to gas and oil for cooking, from pumping water to running water exist great assistances of digitalization. $^{19}$

\section{BETTER FAMILIAL INTERACTION:}

Digitalization has made it easy to connect with far-off family members. In the global village, distance matter no more, as chatting and video calling has brought easiness to contact with a loved one in one click. Parents can

19 Ruth Cowan Schwartz, "The 'Industrial Revolution' in the Home: Household Technology and Social Change in the 20th Century," Domestic Ideology and Domestic Work 17, no. 1 (2012): 375-97, https://doi.org/10.1515/9783110968842.375. 
The Scholar Islamic Academic Research Journal

Vol. 7, No. 2 || July-December 2021 || P. 1-19

https://doi.org/10.29370/siarj/issue13ar1

take care of their children from far-off, having their location and details in their mobiles. ${ }^{20}$

\section{AWARENESS:}

Technology has provided much assistance to women especially as they are more aware of their rights now. There are women protection helplines and apps. They can call and inform police sharing their location. Women have got many legal rights and protection because of technological inventions. In family life, women's role has evolved and now they have more rights. ${ }^{21}$

\section{NEGATIVE IMPACTS OF SOCIAL MEDIA:}

Many people focus on the good aspects of technology, and only a few have looked at the overall turmoil that families face as a result of their utilization of technology. Technology has provided humankind ease but at the great cost of familial pleasures.

When families are requested to document their usage of technology in the house, it appears that there is a contradiction. Typically, investigations encourage families to estimate how much time their children spend with technology and how long they spend with it. Several parents state unequivocally that the computer's purpose at home is to assist with education and chores. However, investigations have revealed that computers are primarily utilized for gaming. When comparing software utilized at home to that available at school, it was discovered that there was more entertainment-oriented software than academic software. In

\footnotetext{
20 Background Note, "Families and New Technologies" (2021 International Day of Families Families, 2021).

${ }^{21}$ Judith E. Tucker, Women, Family, and Gender in Islamic Law (Cambridge University Press, n.d.).
} 
The Scholar Islamic Academic Research Journal

Vol. 7, No. 2 || July-December 2021 || P. 1-19

https://doi.org/10.29370/siarj/issue13ar1

most houses, technology is heavily employed for communication. Adults and teens communicate with friends, partners, and family members via computers (email) and cell phones. Unfortunately, the use of technology, particularly cell phones, has increased. ${ }^{22}$

\section{EXCESSIVE USE OF MEDIA AND FAMILY ALIENATION:}

Excessive use of technology has alienated the youth from their relatives. They are so busy in the "digital relatives" that they don't have much time for their blood relations. According to survey-based research conducted among master's level students in Islamabad, technology and social media were enormously affecting family life. The findings of the research show that a majority of $94 \%$ of the students agreed that excessive use of social media affected their family life negatively resulting in their isolation and alienation from relatives. ${ }^{23}$ This shows that technology is influencing the family's lives mechanically.

\section{TELEVISION AND MARITAL LIFE DISCOURSE:}

Television, as a popular product of digitalization, was once; only available to the upper class but now it has turned to be a domestic need. TV dramas not only provide entertainment but also play a vital role in shaping the social behavior of the viewer. There are many studies conducted on Indian dramas that show that how they have imparted unhealthy effects on a

\footnotetext{
${ }^{22}$ Villegas, "The Influence of Technology on Family Dynamics."

${ }^{23}$ Social Media and Youth in Pakistan: Implications on Family Relations, Rabia Ali, Global Media Journal, Vol 14, 26-6-2016
} 
The Scholar Islamic Academic Research Journal

Vol. 7, No. 2 || July-December 2021 || P. 1-19

https://doi.org/10.29370/siarj/issue13ar1

family system such as the drama "Kyun k Sas bhi kabhi bahhu thi"etc. ${ }^{24}$

The content shown and presented on television affects personality development. Presenting the content portraying family politics, fights, hatreds and infidelity in marital relations, have destructive impacts on the psychology of an individual living in a family setting.

Pakistani drama industry was popular for its photography, content, and moral values. But now it has also transformed presenting divorce, Halalah, confusions, Khula'a, forced marriages, illicit relations, vulgarity, and family rifts that ultimately lead to family deterioration. Such as, Malik Adnan in his research paper has highlighted the dramas that are directly contrary to Islamic teachings. ${ }^{25}$

\section{CONCLUSION:}

Family, as the primary unit of society, has a crucial role in civilizationbuilding and development. In this age of digitalization, the family has been enormously affected by technological swifts. To conclude, we can say that technology has transformed the way families used to interact and interconnect. Living standards and socialization modes are also influenced greatly. For generations to follow, technology's constant evolution and

\footnotetext{
${ }^{24}$ Raghavan, Priya. (2008) "Family, politics and popular television: an ethnographic study of viewing an Indian serial melodrama." Ph.D. diss., Victoria University; Al Helal, Md Abdullah. (2013) "The Impacts of Indian Drama Serials on Bangladeshi Family System: An overview of People's Perception." Journal of Social Sciences and Humanities, vol.8:2, 24-34

${ }^{25}$ Malik Adnan, "Television and Marital Family Discourses in Pakistan: Islamic Values and Urdu Drama Narratives," Pakistan Journal of Islamic Research, 2004, 103-12.
} 
The Scholar Islamic Academic Research Journal

Vol. 7, No. 2 || July-December 2021 || P. 1-19

https://doi.org/10.29370/siarj/issue13ar1

adjustments will play a role in the conflicts that individuals and families confront. Individuals and families will continue to battle with what is developmental technology for kids, safety worries about the internet and social media use, and managing work-family time.

Islam as a complete code of life provides basic principles to tackle the challenges caused by technological swift. Islam entitles both husband and wife to play their duties lawfully and devotedly. It provides strategies for nurturing children and strengthening the family system. More studies should look into the contradictory roles that technology plays in familial well-being, as well as the level of inner strife that families and parents may experience between what they do with technology and what is socially acceptable. Future research should look into various family roles and viewpoints (for example, kids, grandparents, and fathers), as this may contribute to a better understanding of how influences familial well-being. Islam supports technology and digital advancements, but it prohibits their negative use. Everything beneficial for family affairs and humankind, Islam allowed that with certain limitations such as forbidding excessive use.

Technology may be regarded as the blessing of Allah as it benefits human beings but it becomes a curse when improperly used. Technology can be used to communicate, socialize and strengthen family bonds as it is desirable in Islam. Television and visual media are powerful tools of technology to promote family-related moral values, such as writers should write dramas promoting women's strength instead of flaws. Drama scripts can portray the importance and need of family life. Pakistan, as an Islamic Ideological state, must take steps to minimize the negative impacts of 
The Scholar Islamic Academic Research Journal

Vol. 7, No. 2 || July-December 2021 || P. 1-19

https://doi.org/10.29370/siarj/issue13ar1

technology, such as banning sites that promote vulgarity as it has a bad impact on marital life. Technology especially social media can play a pivotal role in strengthening family bonds if used properly

\section{(1) (8)}

BY NC SA This work is licensed under a Creative Commons

Attribution-NonCommercial-ShareAlike 4.0 International (CC BY-NC-SA 4.0) 